\title{
Effects of metal contaminants on the development of the common Antarctic sea urchin Sterechinus neumayeri and comparisons of sensitivity with tropical and temperate echinoids
}

\author{
C. K. King ${ }^{1, *}$, M. J. Riddle ${ }^{2, * *}$ \\ ${ }^{1}$ School of Biological Sciences, University of Sydney, New South Wales 2006, Australia \\ ${ }^{2}$ Australian Antarctic Division, Channel Highway, Kingston, Tasmania 7050, Australia
}

\begin{abstract}
A toxicity test was developed to examine the effects of metal contaminants on the sensitive early life history stages of the common Antarctic echinoid Sterechinus neumayeri (Meissner). Embryos and larvae of the sea urchin were exposed to the metals copper, cadmium, zinc and lead, and the effects of each metal on development to hatched blastulae after 6 to $8 \mathrm{~d}$, and to 2-arm plutei after 20 to $23 \mathrm{~d}$ were monitored. These metals are common in Antarctic marine environments and are often found at elevated levels at sites subject to anthropogenic inputs. For all metals tested, the longterm test to the 2-arm pluteus stage was more sensitive than the short-term test. Copper was the metal most toxic to developing embryos and larvae of $S$. neumayeri with EC50s of $11.4 \mathrm{ug} \mathrm{l}^{-1}$ and $1.4 \mu \mathrm{g} \mathrm{l}^{-1}$ following 6 to $8 \mathrm{~d}$ and 20 to $23 \mathrm{~d}$ exposure respectively. Exposure to cadmium at concentrations greater than $2 \mathrm{mg} \mathrm{l}^{-1}$ caused a significant decrease in the proportion of embryos developing normally to hatched blastulae $\left(\mathrm{EC} 50=6.9 \mathrm{mg} \mathrm{l}^{-1}\right.$ ) and concentrations greater than $0.2 \mathrm{mg} \mathrm{l}^{-1}$, caused a decrease in normal 2-arm plutei. EC50 values calculated for zinc were 2230 and $326.8 \mu \mathrm{g} \mathrm{l}^{-1}$ for the short- and long-term tests respectively. Lead had no effect on development of embryos following $7 \mathrm{~d}$ exposure at all concentrations tested (up to $3.2 \mathrm{mg} \mathrm{l}^{-1}$ ). As the concentration of $\mathrm{Cu}$ shown to inhibit development of $S$. neumayeri is similar to levels found at impacted sites in Antarctic nearshore environments, results of this study indicate that this metal may have an impact on the development of $S$. neumayeri. The sensitivity of $S$. neumayeri to copper and cadmium in tests based on development to hatched blastulae ( 6 to $8 \mathrm{~d}$ ) are generally comparable to results of tests on echinoids from tropical and temperate regions that use development to 2-arm plutei (2 to $4 \mathrm{~d}$ ) as the end-point. However, the Antarctic species is more sensitive to copper and cadmium than the tropical and temperate species if the tests are continued to the same stage of development, the pluteus larva (20 to $23 \mathrm{~d}$ for the Antarctic species). Comparing the tolerance of a key developmental stage common to all planktotrophic sea urchins may be more ecologically relevant than simply comparing exposure over a fixed period of time, because for an embryo to survive to adulthood it must successfully complete all development stages. This is the first reported evidence that Antarctic species could be more sensitive to contaminants than species from warmer regions.
\end{abstract}

KEY WORDS: Antarctic $\cdot$ Contaminant $\cdot$ Metals $\cdot$ Exposure $\cdot$ Sensitivity $\cdot$ Toxicity test $\cdot$ Echinoid $\cdot$ Development $\cdot$ Sterechinus neumayeri

\section{INTRODUCTION}

Concentrations of naturally occurring metals in Antarctic marine environments are typically very low

\footnotetext{
*Present address: CSIRO Division of Energy Technology, New Illawarra Rd, Lucas Heights, New South Wales 2234, Australia
}

**Corresponding author. E-mail: martin.riddle@antdiv.gov.au
(Honda et al. 1987, Abollino et al. 1996). The average concentration of several metals in seawater sampled from 12 locations in East Antarctica were $0.067 \mathrm{\mu g} \mathrm{l}^{-1}$ for cadmium, $0.52 \mathrm{\mu g} \mathrm{l}^{-1}$ for copper, $0.33 \mathrm{\mu g} \mathrm{l}^{-1}$ for lead and $0.87 \mu \mathrm{g} \mathrm{l}^{-1}$ for zinc (Honda et al. 1987). However, metals and other contaminants of anthropogenic origin are found at much higher levels in sediments and seawater at some locations. In particular, sites previously used for waste disposal or currently used for fuel han-

() Inter-Research 2001 
dling and sites adjacent to sewage outfalls often have increased levels of contaminants (Lenihan et al. 1990, Risebrough et al. 1990, Cripps 1992a,b, Green \& Nichols 1995, Deprez et al. 1999). Concentrations of $200 \mu \mathrm{g} \mathrm{l}^{-1}$ copper, $6 \mu \mathrm{g} \mathrm{l}^{-1}$ cadmium and $2000 \mathrm{\mu g} \mathrm{l}^{-1}$ zinc have been reported in water from a melt-pond at a disused waste disposal site near Casey Station, Wilkes Land, Antarctica (Cole et al. 2000), and $25 \mathrm{mg} \mathrm{kg}^{-1}$ copper and $70 \mathrm{mg} \mathrm{kg}^{-1}$ zinc were reported in marine sediments from a bay adjacent to the site (Scouller et al. 2000). Although contaminated areas are generally confined to within $\sim 200 \mathrm{~m}$ of Antarctic stations, they have been reported to cause effects on biota and to cause localised changes to benthic communities (Lenihan et al. 1990, 1995, Lenihan 1992, Lenihan \& Oliver 1995).

The ecological significance of contaminants on terrestrial and marine communities in the Antarctic is largely unknown. Ecological response to contamination may depend on a number of factors, including the species in the receiving environment, their mode of life, their mode of reproduction and development, their life history stage, other sources of stress and the synergistic effects of complex mixtures of contaminants. Although there is extensive information on the bioaccumulation of contaminants in a wide range of Antarctic organisms (e.g. Honda et al. 1987, Ernst \& Klages 1991, Berkman \& Nigro 1992, Petri \& Zauke 1993, Viarengo et al. 1993, Locarnini \& Presley 1995, Bargagli et al. 1996, 1998, de Moreno et al. 1997), very few studies of the acute and chronic effects of exposure and the response of marine biota to contaminants in polar regions have been reported (Percy 1977, Percy \& Mullin 1977, Riebel \& Percy 1990, Chapman \& McPherson 1993, Lenihan et al. 1995, Cleveland et al. 1997, Ling et al. 1998, Duquesne et al. 2000).

A number of animals including echinoderms, molluscs and crustaceans are common in Antarctic marine habitats and were assessed for their suitability as indicator organisms to investigate the effects of metals on Antarctic biota. Early life history stages of marine invertebrates, including echinoids, are known to be highly sensitive to environmental stresses, including contaminants, and are therefore widely used as test species in environmental monitoring programs (e.g. Kobayashi 1980, Klockner et al. 1985, Ringwood 1992, Bay et al. 1993). Despite the extensive range of toxicity test methods developed and used routinely in tropical and temperate regions, very few methods have been developed for Antarctic species (Lenihan et al. 1995, Cleveland et al. 1997, Ling et al. 1998, Duquesne et al. 2000). This study is the first reported using embryos and larvae of a local Antarctic sea urchin.

Sterechinus neumayeri (Meissner) (Order Echinoidea, Family Echinidae) is one of the most common and widely distributed sea urchins in Antarctic coastal waters (Arntz et al.1994, Brey \& Gutt 1991). It is reproductively mature from winter until early summer, spawning between May and December (Pearse \& Giese 1966). Embryos and early larval stages of this species have been collected from the plankton in areas adjacent to McMurdo Station in early November and December (Bosch et al. 1987), which, when coupled with known development times in laboratory-reared cultures, suggests a spawning peak from October to December. Development of this species from a relatively small egg of $180 \mu \mathrm{m}$ diameter, through a feeding pluteus larva to metamorphosis and settlement, is similar to other planktotrophic echinoids from temperate and tropical regions (Bosch et al. 1987). Rate of development, however, is considerably slower (some 2 to 10 times), due to the low temperatures in Antarctic waters at which development occurs (Bosch et al. 1987, Stanwell-Smith \& Peck 1998). In cultures reared at -1 to $0^{\circ} \mathrm{C}$, the blastula stage is reached 2 to $3 \mathrm{~d}$ post fertilisation, and the embryo hatches from its fertilisation membrane after 5 to $6 \mathrm{~d}$ (Bosch et al. 1987, C.K.K. pers. obs.). The gastrula stage is reached after 9 to $10 \mathrm{~d}$ and develops into an early pluteus with a functional gut and the first pair of larval arms supported by skeletal rods after approximately $20 \mathrm{~d}$ (Bosch et al. 1987, C.K.K. pers. obs.). The juvenile is formed after 3 to $4 \mathrm{mo}$ in the plankton (Bosch et al. 1987).

The objective of this study was to determine the response of the embryos and larvae of Sterechinus neumayeri to metal contaminants that are common in Antarctic marine environments using toxicity test procedures based on its early life history. Responses of the embryos and larvae to specific common metals were assessed in order to determine whether contaminants at the levels that have been measured at various sites in the Antarctic are likely to cause harm to local fauna and flora. The long-term test developed is analogous to the sea urchin larval development test that is commonly used in temperate regions (Esposito et al. 1986, Pagano et al. 1986, Dinnel 1990, Kobayashi 1991, 1994, Bay et al. 1993, Bay \& Greenstein 1994). By developing a similar test, it is possible to determine whether the larvae of the Antarctic species are of comparable sensitivity and respond to contaminants at concentrations similar to those that cause an effect in related species from temperate and tropical regions. This information can then be used to determine whether environmental standards and guidelines for emission of contaminants in lower latitude regions can be applied to the Antarctic, or whether standards based on the responses of local organisms are needed. The limited information available on the sensitivity of Antarctic fauna to pollutants (Ernst \& Klages 1991, Chapman \& McPherson 1993, Ling et al. 1998, Duquesne et al. 2000) suggests 


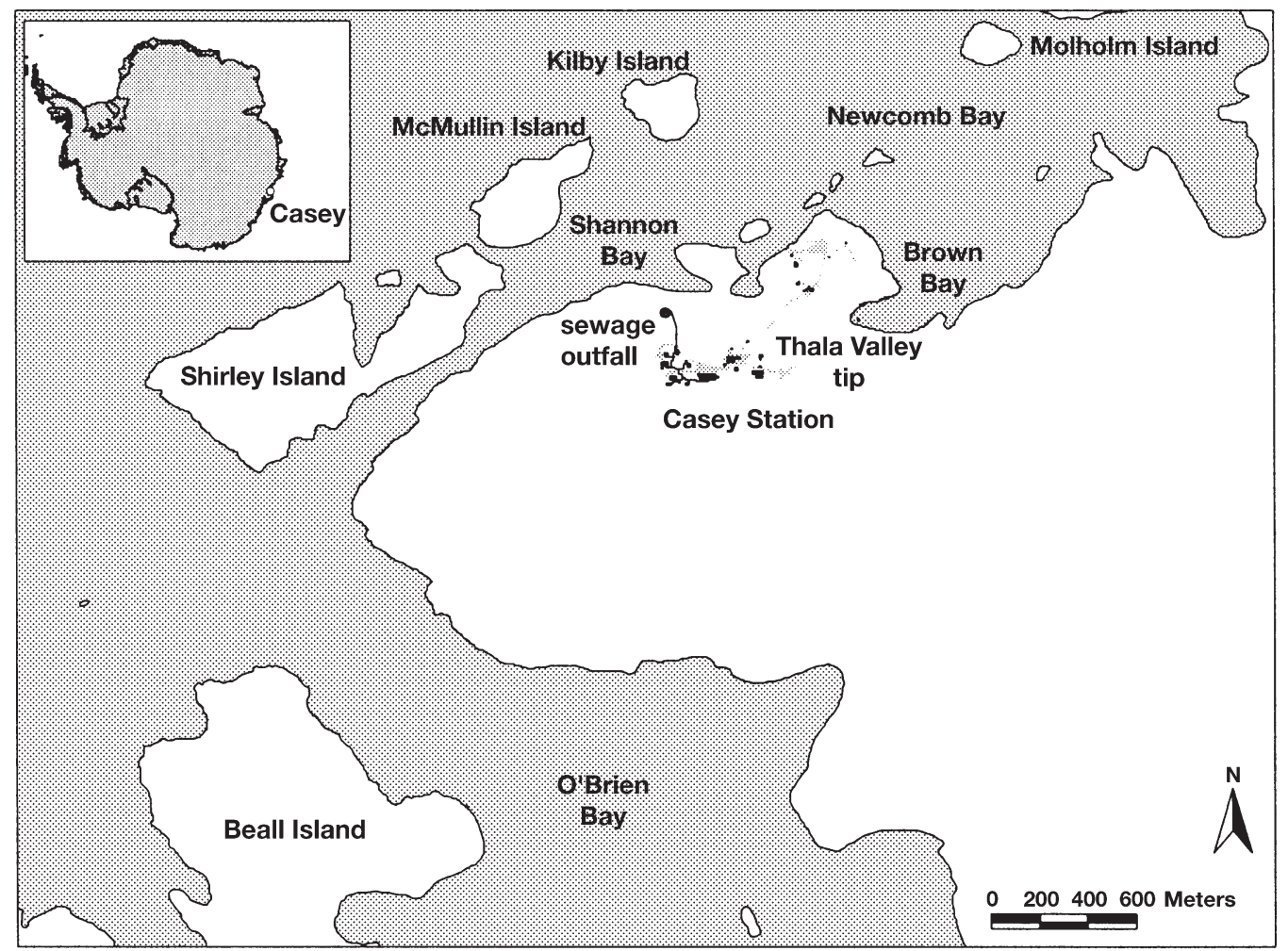

Fig. 1. Location of sampling sites in relation to the Australian Antarctic research station, 'Casey'

that polar and temperate species exhibit deleterious effects of exposure to contaminants at similar concentrations. However, very few species have been investigated, and more information on a range of ecologically important and sensitive species such as $S$. neumayeri is required before the question of the sensitivity of Antarctic species can be properly addressed and used to establish environmental guidelines.

\section{MATERIALS AND METHODS}

Collection. Mature Sterechinus neumayeri were collected by divers from sub-tidal populations in O'Brien Bay and Brown Bay near Casey Station (Fig. 1). They were transported to the laboratory in buckets of seawater and were kept in 601 aquaria (maximum 8 ind. aquaria $^{-1}$ ) with continuous aeration and biological filtration at a temperature of $0 \pm 1^{\circ} \mathrm{C}$ and a salinity of $34 \pm$ $1 \mathrm{ppt}$. Urchins were monitored for at least $24 \mathrm{~h}$ before being used in tests, to allow them to acclimatise to the test temperature and to identify individuals in poor condition that may not have spawned healthy gametes.

Induction of spawning and preparation of gametes. Sea urchins were induced to spawn by injection of 3 to $5 \mathrm{ml}$ of $0.5 \mathrm{M} \mathrm{KCl}$. After injection, individuals were placed singly into plastic containers with 250 to $300 \mathrm{ml}$ of $0.45 \mu \mathrm{m}$ filtered seawater (FSW) in a water bath at $0 \pm 1^{\circ} \mathrm{C}$. Gametes were collected during the first $20 \mathrm{~min}$ of spawning. Spermatozoa were collected using a pipette, directly from the surface of the urchin to prevent dilution with water and consequent activation. Pipette tips containing sperm were held on ice until the sperm was ready to be used in fertilisation. Spawning females were inverted (oral side up) over dishes of FSW so that the genital pores were submerged and spawned eggs were allowed to settle to the base of the dish. Eggs were collected using a wide bore pipette and washed several times in fresh FSW through a $250 \mu \mathrm{m}$ mesh to remove large extraneous material. The condition of eggs was then assessed visually for uniformity of shape and size and homogeneous yolk content. Sperm were diluted with FSW, and their motility checked immediately prior to being added to the eggs.

Fertilisation. Insemination using eggs from a single female and sperm from 1 or 2 males took place within $1 \mathrm{~h}$ of spawning to ensure gametes remained healthy. To avoid polyspermy, the minimum amount of sperm necessary to give 75 to $95 \%$ fertilisation was added. The eggs and sperm were mixed with a perforated plunger in the beaker to keep them suspended during fertilisation. Fertilised eggs (as indicated by the elevation of the fertilisation membrane) were washed through a $300 \mu \mathrm{m}$ mesh with several changes of FSW to 
remove excess sperm and any remaining debris before being transferred to experimental test tubes. Once fertilised, the concentration of embryos in the suspension was determined using a Sedgewick-Rafter counting cell and adjusted to 50 to 60 embryos $\mathrm{ml}^{-1}$. Only batches of eggs with at least $75 \%$ successful fertilisation were used in tests.

Toxicity tests. Tests were conducted in glass test tubes (Borex $13 \times 100 \mathrm{~mm}$ disposable culture tubes) and 4 replicate test tubes were used per treatment. Within $3 \mathrm{~h}$ of fertilisation, $1 \mathrm{ml}$ of the embryo suspension was placed into each test tube containing $7 \mathrm{ml}$ of the test solution, to give a final volume of $8 \mathrm{ml}$ and a density of 6 to 8 embryos $\mathrm{ml}^{-1}$. The embryo suspension was kept well mixed using a perforated plunger during withdrawal of $1 \mathrm{ml}$ aliquots to ensure each test tube received the same number of eggs. Test tubes were covered with parafilm to minimise evaporation of test solution and to prevent contamination, and they were kept in an environmental chamber at a temperature of $0 \pm 0.5^{\circ} \mathrm{C}$ for the duration of the test.

Test solutions. Seawater used as the control and dilution water in all experiments was collected approximately $100 \mathrm{~m}$ from the shore in O'Brien Bay. This bay is not subject to any direct contamination and was considered a control site. Chemical analysis of seawater sampled from this site has revealed very low levels, generally below detection limits or similar to procedural blanks (5 ppb or lower, measured using Inductively Coupled Plasma Mass Spectrometry, ICPMS) of a range of potential contaminants (I. Snape pers. comm.). Seawater was pumped through a hole in the sea-ice and stored in a 10001 container. Within $48 \mathrm{~h}$ of the start of each test, approximately $20 \mathrm{l}$ of seawater was filtered to $0.45 \mu \mathrm{m}$ and stored in black polyethylene carboys in an environmental chamber at $0 \pm 0.5^{\circ} \mathrm{C}$ until used in tests. Salinity, $\mathrm{pH}$ and dissolved oxygen of FSW was checked and adjusted if required (salinity $=34 \pm 1 \mathrm{ppt}_{i} \mathrm{pH}=8.0$ to 8.2 ; dissolved oxygen $>70 \%$ ). Metal stock solutions were made in deionised water prior to tests and stored in airtight polyethylene containers at $4^{\circ} \mathrm{C}$. Four metals that are common in meltwater and sediments from contaminated sites in Antarctica, including at Casey (Deprez et al. 1999), were tested; they are copper $\left(\mathrm{CuSO}_{4} \cdot 5 \mathrm{H}_{2} \mathrm{O}\right)$, cadmium $\left(\mathrm{CdCl}_{2}\right)$, zinc $\left(\mathrm{ZnSO}_{4} \cdot 7 \mathrm{H}_{2} \mathrm{O}\right)$, and lead $\left[\left(\mathrm{CH}_{3} \mathrm{COO}\right)_{2} \mathrm{~Pb} \cdot 3 \mathrm{H}_{2} \mathrm{O}\right]$. Metal stock solutions were diluted to the required concentrations in test tubes immediately prior to induction of spawning on the day of testing.

Test end-points. Two end-points were used in tests; normal embryonic development to hatched blastulae ( 6 to $8 \mathrm{~d}$ ), and normal embryonic and larval development to 2 -arm plutei ( 20 to $23 \mathrm{~d}$ ). At the termination of tests, larvae were fixed using $0.2 \mathrm{ml}$ of $5 \%$ buffered formalin per test tube, and they were examined using a compound microscope at a magnification of $100 \times$. The number of normally developed larvae and the total number of larvae present in cultures were counted. Mortality, abnormalities and slower development relative to controls were the criteria used to determine variations from normal development.

Statistical analysis. Probit analysis or Trimmed Spearman Karber tests (if assumptions of the probit analysis were not met) were used to estimate the concentration of each test solution causing abnormal development in $50 \%$ of test individuals (EC50 values). No observable effect concentration (NOEC) and lowest observable effect concentration (LOEC) values were calculated using Dunnett's multiple comparison test. To investigate repeatability and precision of tests, the average EC50 and coefficient of variation (CV) were calculated. Analyses of variance (ANOVA) and Student-Newman-Keuls (SNK) tests were used to test for differences in the number of deformed embryos and larvae between treatments and for differences between replicate tests. Cochran's $C$-test was used prior to ANOVA to test for homogeneity of variance $(\mathrm{p}=$ $0.05)$, and data was $\ln (x+1)$ transformed if required to remove heterogeneity.

Table 1. Sterechinus neumayeri. Summary of EC50 (concentration of each test solution causing abnormal development in $50 \%$ of test individuals), CV (coefficient of variation), NOEC (no observable effect concentration) and LOEC (lowest observable effect concentration) average values for embryos and larvae exposed to copper, cadmium, zinc and lead

\begin{tabular}{|c|c|c|c|c|c|c|}
\hline Toxicant & Stage & No. of tests & $\begin{array}{c}\text { EC50 } \\
\left(\mu g l^{-1}\right)\end{array}$ & $\begin{array}{l}\mathrm{CV} \\
(\%)\end{array}$ & $\begin{array}{l}\text { NOEC } \\
\left(\mu \mathrm{g} \mathrm{l}^{-1}\right)\end{array}$ & $\begin{array}{r}\mathrm{LOEC} \\
\left(\mu \mathrm{g} \mathrm{l}^{-1}\right)\end{array}$ \\
\hline Copper & $\begin{array}{l}6-8 \text { d hatched blastula } \\
20-23 \text { d } 2 \text {-arm pluteus }\end{array}$ & $\begin{array}{r}10 \\
1\end{array}$ & $\begin{array}{r}11.4 \\
1.4\end{array}$ & $\begin{array}{c}31.5 \\
-\end{array}$ & $\begin{array}{r}8 \\
<2\end{array}$ & $\begin{array}{r}12 \\
2\end{array}$ \\
\hline Cadmium & $\begin{array}{l}6-8 \text { d hatched blastula } \\
20-23 \text { d } 2 \text {-arm pluteus }\end{array}$ & $\begin{array}{l}5 \\
4\end{array}$ & $\begin{array}{r}6940 \\
-\end{array}$ & $\begin{array}{c}37.6 \\
-\end{array}$ & $\begin{array}{l}2000 \\
<200\end{array}$ & $\begin{array}{r}4000 \\
200\end{array}$ \\
\hline Zinc & $\begin{array}{l}6-8 \text { d hatched blastula } \\
20-23 \text { d } 2 \text {-arm pluteus }\end{array}$ & $\begin{array}{l}6 \\
3\end{array}$ & $\begin{array}{r}2230 \\
326.8\end{array}$ & $\begin{array}{l}20.5 \\
24.6\end{array}$ & $\begin{array}{l}800 \\
160\end{array}$ & $\begin{array}{r}1200 \\
320\end{array}$ \\
\hline Lead & $6-8$ d hatched blastula & 3 & - & - & 3200 & $>3200$ \\
\hline
\end{tabular}




\section{RESULTS}

The average point estimates including EC50 (and CV), NOEC and LOEC values for each of the metals tested are shown in Table 1. EC50 values for individual tests could not always be calculated; hence no average values for these tests (lead at 6 to $8 \mathrm{~d}$ and cadmium at 20 to $23 \mathrm{~d}$ test) are shown.

\section{Copper}

Exposure of embryos to increasing copper concentrations caused a significant increase in the occurrence of abnormal hatched blastulae. Abnormal development was observed in concentrations above $5 \mathrm{\mu g} \mathrm{l}^{-1}$ for 2 tests (ANOVA, $\mathrm{Cu}, F=251.67, \mathrm{p}<0.001$ ) and above $4 \mathrm{\mu g} \mathrm{l}^{-1}$ for 8 tests (ANOVA, Test $\times \mathrm{Cu}, F=12.56, \mathrm{p}<$ 0.001 ). Point estimates were slightly less sensitive than ANOVA results, with exposure to approximately $12 \mu \mathrm{g}$ $\mathrm{l}^{-1}$ of copper (average LOEC for 10 tests, Table 1) or greater resulting in a decrease in normal development (Fig. 2a), with individuals often failing to hatch from their fertilisation membranes after 6 to $8 \mathrm{~d}$. At concentrations below approximately $8 \mu \mathrm{g} \mathrm{l}^{-1}$ (average NOEC, Table 1), there was no significant disruption to development to the hatched blastula stage. Mortality of

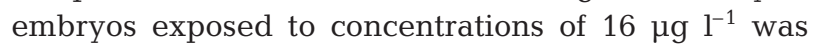
high, and no normal development was observed at $32 \mu \mathrm{g} \mathrm{l}^{-1}$ or above. The concentration of copper causing $50 \%$ abnormal development after 6 to $8 \mathrm{~d}$ exposure (Table 1) was $11.4 \mathrm{\mu g} \mathrm{l}^{-1}$ (average EC50, Table 1, range 5.2 to $16.4 \mathrm{\mu g} \mathrm{l}^{-1}$ ). The effect of copper on development to 2 -arm plutei is shown in Fig. 2b. Development to 2 -arm plutei was significantly disrupted $(\mathrm{p}<0.01)$ in concentrations as low as $2 \mu \mathrm{g} \mathrm{l}^{-1}$ (ANOVA, 2 tests, $\mathrm{Cu}$, $F=164.51, \mathrm{p}<0.001$; Fig. 2b). An EC50 value of $1.4 \mu \mathrm{g}$ $\mathrm{l}^{-1}$ could be calculated for only 1 of the 4 tests of the effects of exposure to copper on development to the 2-arm pluteus stage (Table 1).

\section{Cadmium}

The number of abnormal hatched blastulae increased with exposure to increasing concentrations of cadmium up to $8 \mathrm{mg} \mathrm{l}^{-1}$ (ANOVA, 2 tests, Test $\times \mathrm{Cd}_{\text {, }}$ $F=12.29, \mathrm{p}<0.001$; Fig. 3a). At concentrations of $4 \mathrm{mg} \mathrm{l}^{-1}$ and above, there was a significant decrease in the number of normal hatched blastulae in 5 tests $(p<0.01$; Fig. 3a; Table 1, LOEC). No effect on development was observed at concentrations of $2 \mathrm{mg} \mathrm{l}^{-1}$ or less (Table 1, NOEC). EC50 values were estimated for 5 tests and ranged from 3.8 to $9.9 \mathrm{mg} \mathrm{l}^{-1}$, with an average of $6.9 \mathrm{mg} \mathrm{l}^{-1}$ and $(\mathrm{CV}=37.6 \%$, Table 1). Even at
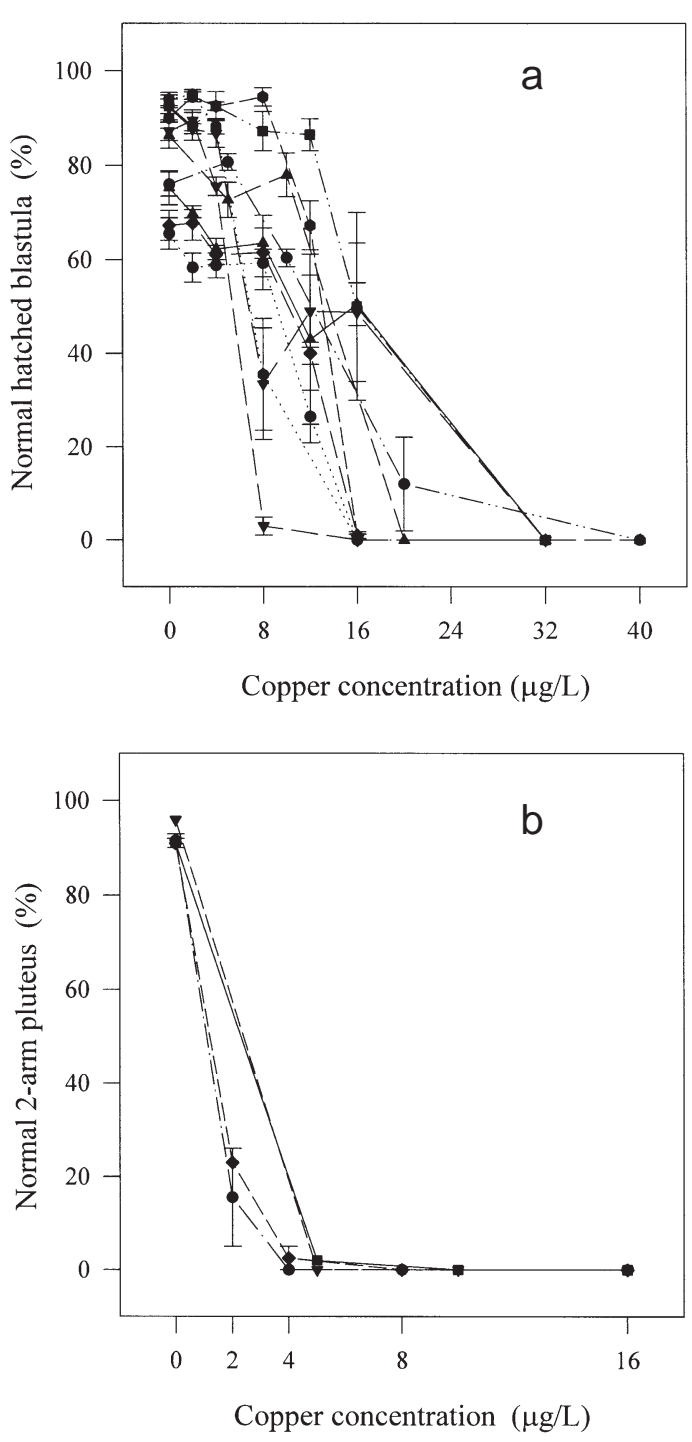

Fig. 2. Sterechinus neumayeri. Effect of copper on development: (a) to hatched blastula following 6 to $8 \mathrm{~d}$ exposure; (b) to 2 -arm pluteus following 20 to 23 d exposure (each line represents single test)

the highest concentration tested $\left(8 \mathrm{mg} \mathrm{l}^{-1}\right)$, a proportion of embryos developed normally to hatched blastulae. Development to 2-arm plutei was disrupted following exposure to $200 \mathrm{\mu g} \mathrm{l}^{-1}$ of cadmium, and no normal larvae developed in cadmium concentrations greater than $500 \mathrm{\mu g} \mathrm{l}^{-1}$ (Fig. 3b; ANOVA, 2 tests, Cd, $F=41.6, \mathrm{p}<0.001)$. There were significantly more normal 2-arm plutei in the controls than in any of the treatments $(p<0.01)$. As the effect of cadmium on development to the 2-arm pluteus stage was so dramatic at all the concentrations tested, no EC50 values could be calculated for these tests. However, they would have been well below the average LOEC of $0.2 \mathrm{mg} \mathrm{l}^{-1}$ (Table 1). 

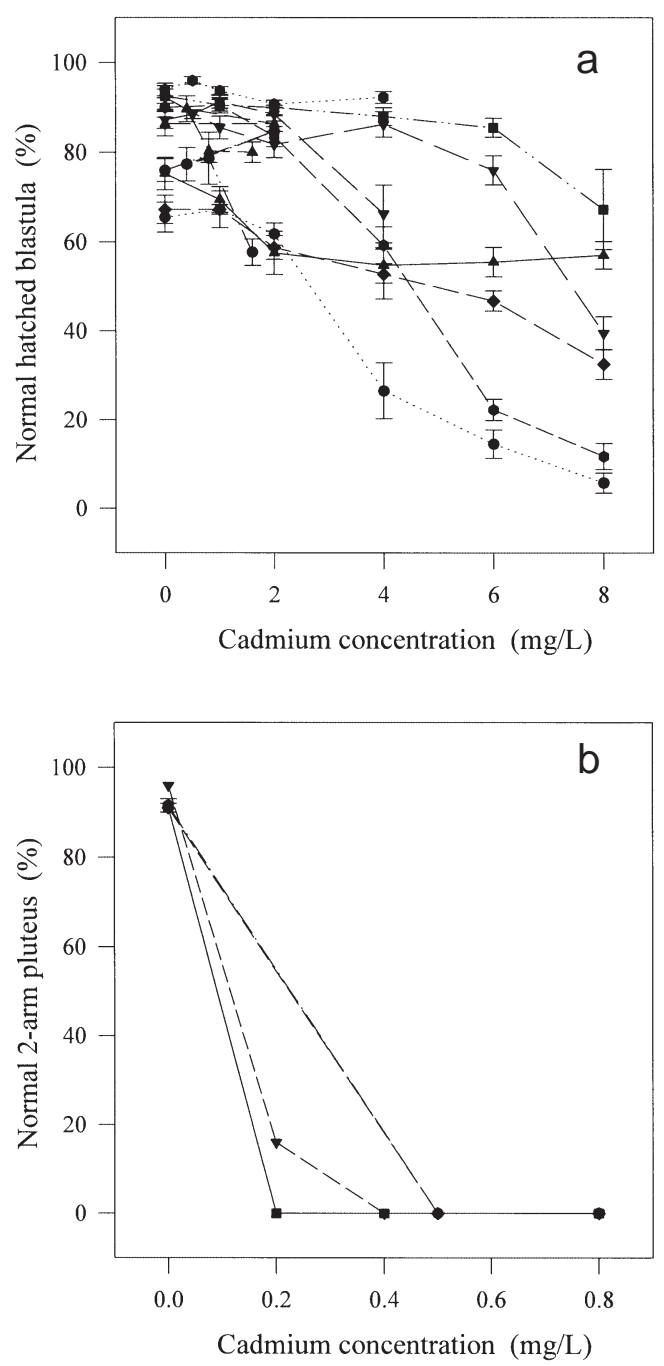

Fig. 3. Sterechinus neumayeri: Effect of cadmium on development (a) to hatched blastula, following 6 to $8 \mathrm{~d}$ exposure; (b) to 2-arm pluteus, following 20 to $23 \mathrm{~d}$ exposure (each line represents single test)

\section{Zinc}

Concentrations of zinc up to $0.8 \mathrm{mg} \mathrm{l}^{-1}$ did not adversely affect development of Sterechinus neumayeri embryos to hatched blastulae (Table 1, NOEC). A significant decrease $(p<0.01)$ in the number of normally developing embryos was observed in 6 tests between 1.6 and $2 \mathrm{mg}^{-1}$ (ANOVA, Test $\times \mathrm{Zn}, F=3.91$, $\mathrm{p}<0.001$; Fig. 4a). In the other 4 tests, concentrations tested were lower ( 0 to 0.64 or $1.2 \mathrm{mg} \mathrm{l}^{-1}$ ) and the numbers of embryos developing normally at different concentrations of zinc did not differ (ANOVA, 2 tests, Test $\times \mathrm{Zn}, F=$ 1.91 not significant [ns]; ANOVA, 2 tests, $Z n, F=0.18$ $\mathrm{ns})$. An average of $2.2 \mathrm{mg} \mathrm{l}^{-1}$ of zinc caused a $50 \%$ decrease in normal development in 6 tests (Table 1,
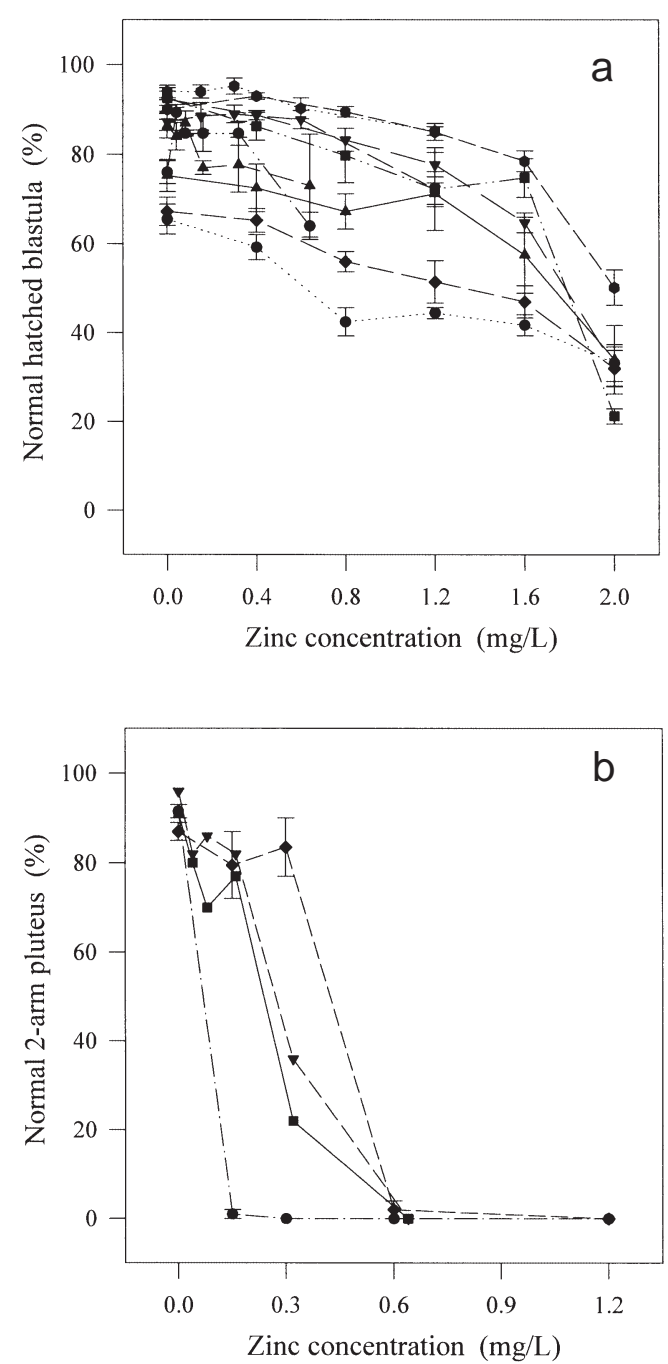

Fig. 4. Sterechinus neumayeri. Effect of zinc on development (a) to hatched blastula, following 6 to $8 \mathrm{~d}$ exposure; (b) to 2 -arm pluteus, following 20 to $23 \mathrm{~d}$ exposure (each line represents single test)

EC50). The lowest rate of normal development recorded was approximately $30 \%$ following exposure to the highest concentration of zinc that was tested $(2 \mathrm{mg}$ $\mathrm{l}^{-1}$ ). As none of the concentrations tested reduced normal development to $0 \%$, the average EC50 value of $2.2 \mathrm{mg} \mathrm{l}^{-1}$ provides a rough estimate only, and more tests using higher concentrations of zinc would be required to obtain more accurate point estimates. Development to 2-arm plutei was inhibited by concentrations of zinc above 150 to $200 \mathrm{\mu g} \mathrm{l}^{-1}$ (Fig. $4 \mathrm{~b}$; Table 1, NOEC = $160 \mu \mathrm{g} \mathrm{l}^{-1}$ ). Less than $5 \%$ of larvae in all tests developed normally at concentrations of $600 \mu \mathrm{g} \mathrm{l}^{-1}$ or greater (Fig. 4b). A zinc concentration of $326.8 \mu \mathrm{g} \mathrm{l}^{-1}(\mathrm{CV}=$ $24.6 \%$ ) was estimated to cause a $50 \%$ decrease in normal development of larvae to 2 -arm plutei (Table 1). 


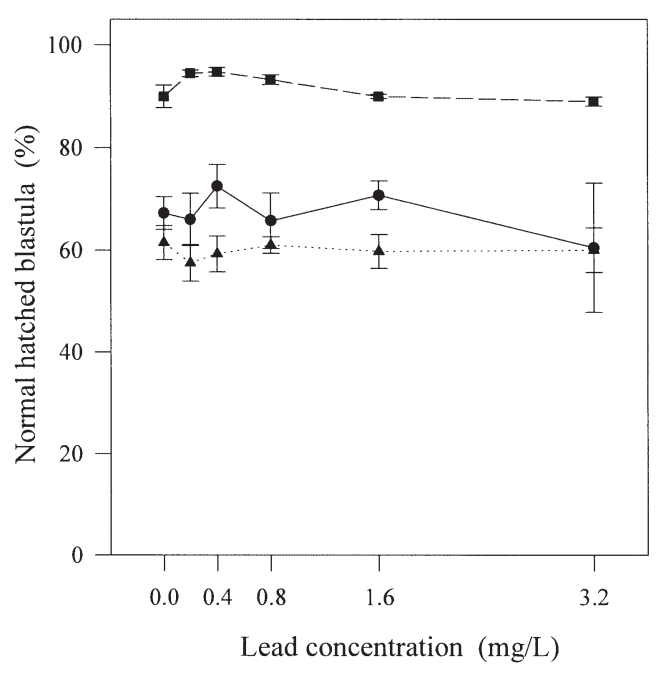

Fig. 5. Sterechinus neumayeri. Effect of lead on development. To the hatched blastula following $7 \mathrm{~d}$ exposure (each line represents a single test)

\section{Lead}

Development of embryos to hatched blastulae was not affected by exposure to lead for $7 \mathrm{~d}$ at any of the concentrations tested (Fig. 5; Table 1, NOEC $3.2 \mathrm{mg} \mathrm{l}^{-1}$; ANOVA, Test $\times \mathrm{Pb}, F=0.62$, ns, $\mathrm{Pb}, F=0.84$, ns). As no response was observed up to the highest concentration, EC50 values could not be calculated and the LOEC was greater than $3.2 \mathrm{mg} \mathrm{l}^{-1}$, the highest concentration tested (Table 1).

\section{DISCUSSION}

\section{Effect of metals on Sterechinus neumayeri and the relative sensitivity of different developmental stages}

Responses of early life history stages to toxicants are stage specific, and for many echinoids tests to the pluteus stage are more sensitive than tests on the same species to earlier developmental stages (Kobayashi 1980, Castagna et al. 1981, Pagano et al. 1986, Dinnel et al. 1989, Bay et al. 1993). Short-term tests to the hatched blastula stage, and long-term tests to the 2-arm pluteus stage were used in this study to compare the sensitivity of different developmental stages of Sterechinus neumayeri to the metals copper, cadmium and zinc. Results of the present study are in agreement with this general finding. For all the toxicants tested, long-term larval development tests to 2-arm plutei were approximately an order of magnitude more sensitive than the short-term embryonic development tests to hatched blastulae. However, the duration of exposure is a confounding factor in direct comparisons of these tests and of the sensitivity of different developmental stages within this species. Tests using the pluteus larvae as the end-point involved exposure of the test organisms for 20 to $23 \mathrm{~d}$ compared to 6 to $8 \mathrm{~d}$ in tests to the hatched blastula. While the increased exposure time in the pluteus tests is likely to contribute to the increased sensitivity, it is not possible to distinguish between the effect caused by different sensitivities of the 2 developmental stages and the effect caused by the different lengths of exposure.

Exposure to very low concentrations of copper (4 to $8 \mathrm{\mu g} \mathrm{l}^{-1}$ ) caused a significant decrease in the number of embryos developing normally to hatched blastulae after 6 to $8 \mathrm{~d}$ exposure (Fig. 2a). The long-term test to 2 -arm plutei over 20 to 23 d was 2 to 4 times more sensitive than the short-term test, with concentrations as low as $2 \mu \mathrm{g} \mathrm{l^{-1 }}$ copper causing a significant decrease in the number of normal larvae (Fig. 2b). In addition, the average EC50 value estimated for long-term tests was approximately 8 times less than that estimated for the short-term tests (Table 1). Exposure to concentrations of cadmium above $2 \mathrm{mg} \mathrm{l}^{-1}$ and $0.2 \mathrm{mg} \mathrm{l}^{-1}$ led to significant increases in the occurrence of abnormal larvae of Sterechinus neumayeri after 6 to $8 \mathrm{~d}$ and 20 to $23 \mathrm{~d}$ respectively (Fig. 4). Development to 2-arm plutei was therefore at least 10 times more sensitive to cadmium exposure than was development to hatched blastulae. Successful development to hatched blastulae decreased in cultures exposed to zinc concentrations of $1.6 \mathrm{mg} \mathrm{l}^{-1}$ or greater (Fig. 4a). The long-term development test to 2-arm plutei was an order of magnitude more sensitive to zinc $\left(\mathrm{EC} 50=326 \mu \mathrm{g} \mathrm{l^{-1 }}\right.$, Table 1$)$. Exposure to lead concentrations up to $3.2 \mathrm{mg} \mathrm{l}^{-1}$ had no effect on developing embryos up to the hatched blastula stage (Fig. 5). Further tests using higher concentrations would therefore be needed to understand the toxicity of lead to $S$. neumayeri.

We cannot say with absolute certainty whether embryos and larvae of Sterechinus neumayeri are likely to encounter metals in Antarctic seawater at concentrations that may cause developmental abnormalities. Very few data on metals in seawater from contaminated sites in the region have been published. However, available information indicates that, of the metals tested, copper is the one most likely to be present at harmful concentrations. Copper has been reported at 0.18 to $1.17 \mu \mathrm{g} \mathrm{l}^{-1}$ in seawater from various localities in Antarctica, with the highest concentrations at sites close to an Antarctic station (Honda et al. 1987). These levels approach the EC50 of $1.4 \mu \mathrm{g}^{-1}$ copper for the long-term test reported here. In addition, copper concentrations of $200 \mu \mathrm{g} \mathrm{l}^{-1}$ have been reported (Cole et al. 2000) in a melt-pool fed by leachate from the disused waste disposal near Casey Station. This site 
drains directly to an enclosed bay that has very little water circulation (Tate et al. 2000) and contains a small population of the urchin. Further, $25 \mathrm{mg} \mathrm{kg}^{-1}$ copper have been reported in sediments from this bay (Scouller et al. 2000). Together these sources may create localised elevated copper that could exceed the EC50 value and so cause adverse effects on the $S$. neumayeri population in the vicinity.

There was considerable variability between replicate tests for each of the metals tested (Figs. 2 to 5). Such variability in the quality of gametes and the response of embryos and larvae obtained from different parents has been reported previously (Emlet et al. 1987, George et al. 1990). Differences in the response of embryos are likely to be due to differences in their parents genetic adaptation, acclimation to environmental conditions, and their physiological condition (Helm et al. 1973, Bayne et al. 1975, 1978). In the present study, adults used to obtain gametes for tests were collected from sites subject to different levels of contaminant input including Brown Bay ('impacted' site) and O'Brien Bay (control site). It is possible that animals acclimated to contaminated conditions may be more tolerant to contaminants than animals from control locations. This was not tested; however, variability within tests was minimised by using eggs from single females only.

\section{Comparisons with related species from temperate and tropical regions}

Whether Sterechinus neumayeri is more or less sensitive to contaminants than temperate and tropical species depends on which end-point is used and compared, and the type of contaminant tested. If the hatched blastula is used as the end-point (6 to $8 \mathrm{~d}$ ) for $S$. neumayeri, then the EC50 for exposure to copper $\left(11.4 \mathrm{\mu g} \mathrm{l}^{-1}\right)$ is within the range of EC50s estimated after a similar period of time (2 to $4 \mathrm{~d}$ exposure) for several non-Antarctic echinoid species with the pluteus larval stage as the end-point (6.3 to $50 \mu \mathrm{g} \mathrm{l}^{-1}$, Table 2). This could be interpreted to suggest that the Antarctic echinoid is sensitive to exposure to copper at concentrations much the same as temperate and tropical species. However, the rate of development of marine invertebrates is dependent on a range of environmental factors, including temperature. The slow rate of development of $S$. neumayeri larvae means that development to the 2-arm pluteus stage takes approximately 10 times as long ( 20 to $23 \mathrm{~d}$ ) as it does in temperate species ( 2 to $3 \mathrm{~d}$ ). Although the time taken to reach a particular developmental stage may differ between related species from different latitudes, for an individual to survive, the same developmental pro- cesses must be completed successfully. A more ecologically realistic comparison than exposure for a set period would therefore be to compare sensitivities of echinoids using tests that continue to the same key stage of development, in this case the pluteus larva, irrespective of the time taken to reach this stage. Using this comparison of sensitivity in a life cycle context, the Antarctic sea urchin S. neumayeri is 5 to 10 times more sensitive to copper (EC50 of $1.4 \mathrm{\mu g} \mathrm{l}^{-1}$ ) and more sensitive to cadmium $\left(<0.2 \mathrm{mg} \mathrm{l}^{-1}\right)$ than species from warmer regions (Table 2). In contrast to copper and cadmium, $S$. neumayeri was relatively insensitive to zinc. After 6 to $8 \mathrm{~d}$ exposure, the zinc EC50 value was 10 times greater than those reported for echinoids from warmer regions (Table 2). The long-term, 20 to $23 \mathrm{~d}$ test using the pluteus larva as the end-point was also slightly less sensitive to zinc than similar tests with temperate and tropical species (Table 2). This is consistent with the earlier finding that Arctic invertebrates are less sensitive to zinc than are animals from lower latitudes (Chapman 1993). Comparisons of the toxicity of lead to different species of echinoids are inconclusive, as few exact point estimates have been calculated for echinoids generally.

\section{Comparisons with other Antarctic and Arctic organisms}

There are few reports of experiments to investigate the effects of common contaminants on Antarctic marine fauna. Sediments contaminated with petroleum hydrocarbons from the vicinity of McMurdo Station were found to be toxic using a series of standard laboratory and field bioassays on local Antarctic and temperate marine organisms including echinoids (Lenihan et al. 1995, Cleveland et al. 1997). However, in these studies, no tests were done using reference toxicants, so direct comparisons with the Sterechinus neumayeri development test cannot be made. More recently, laboratory tests have been done at McMurdo Station, using 3 local amphipods with mortality as an end point after 2 to $14 \mathrm{~d}$ exposure to several metals (Ling et al. 1998). For each species, juveniles were more sensitive than adults to all of the toxicants tested. LC50 values for juveniles of the most sensitive species were $0.2,3,9$ and $>100 \mathrm{mg} \mathrm{l}^{-1}$ for copper, cadmium, zinc and lead respectively after 48 to $96 \mathrm{~h}$ exposure (C. W. Hickey pers. comm.). The results in this study for Paramoera walkeri at McMurdo Station are comparable to those observed for this species in a similar study at Casey Station, where the sub-lethal behavioural effects and lethal toxic effects of cadmium and copper were examined on adults (Greve 1997, Duquesne et al. 2000). For both lethal and sub-lethal 
Table 2. Toxicities (EC50) of metals (copper, cadmium, zinc and lead) to early life history stages of Antarctic sea urchin Sterechinus neumayeri and various tropical and temperate sea urchins. (N.B. Ranges for EC50 values interpreted from results and included when authors reported percentage responses at different concentrations but did not calculate point estimates)

\begin{tabular}{|c|c|c|c|c|}
\hline Metal & Species & Region & $\begin{array}{l}\text { Test duration } \\
\text { and end-point }\end{array}$ & EC50 \\
\hline $\begin{array}{l}\text { Copper } \\
\left(\mu g l^{-1}\right)\end{array}$ & $\begin{array}{l}\text { Sterechinus neumayeri }{ }^{\mathrm{a}} \\
\text { Sterechinus neumayeri }^{\mathrm{a}} \\
\text { Centrostephanus rodgersii }^{\mathrm{m}} \\
\text { Heliocidaris tuberculata }^{\mathrm{o}} \\
\text { Heliocidaris erythrogramma }^{\mathrm{m}} \\
\text { Strongylocentrotuspurpuratus }^{\mathrm{i}} \\
\text { Strongylocentrotus droebachiensis }^{\mathrm{i}} \\
\text { Arbacia punctulata }^{\mathrm{j}} \\
\text { Paracentrotus lividus }^{\mathrm{h}} \\
\text { Anthocidaris crassispina }^{\mathrm{e}} \\
\text { Hemicentrotus pulcherrimus }^{\mathrm{f}} \\
\text { Echinometra mathaei }^{\mathrm{b}} \\
\text { Diadema setosum }^{\mathrm{l}} \\
\text { Diadema setosum }^{\mathrm{l}}\end{array}$ & $\begin{array}{l}\text { Antarctic } \\
\text { Antarctic } \\
\text { Temperate } \\
\text { Temperate } \\
\text { Temperate } \\
\text { Temperate } \\
\text { Temperate } \\
\text { Temperate } \\
\text { Temperate } \\
\text { Temperate } \\
\text { Temperate } \\
\text { Tropical } \\
\text { Tropical } \\
\text { Tropical }\end{array}$ & $\begin{array}{l}6-8 \text { d hatched blastula } \\
20-23 \text { d pluteus } \\
3 \text { d pluteus } \\
3 \text { d pluteus } \\
7 \text { d juvenile } \\
2-3 \text { d pluteus } \\
2-3 \text { d pluteus } \\
2-4 \text { d pluteus } \\
2 \text { d pluteus } \\
1 \text { d pluteus } \\
2 \text { d pluteus } \\
2 \text { d pluteus length } \\
5 \text { h blastula } \\
2 \text { d pluteus }\end{array}$ & $\begin{array}{r}11.4 \\
1.4 \\
11.8 \\
9.4 \\
26.4 \\
6.3 \\
21 \\
14 \\
<32 \\
50-100 \\
10-20 \\
20-50 \\
69 \\
43\end{array}$ \\
\hline $\begin{array}{l}\text { Cadmium } \\
\left(\mathrm{mg} \mathrm{l}^{-1}\right)\end{array}$ & $\begin{array}{l}\text { Sterechinus neumayeri }^{\mathrm{a}} \\
\text { Sterechinus neumayeri }^{\mathrm{a}} \\
\text { Strongylocentrotus purpuratus }^{\mathrm{i}} \\
\text { Strongylocentrotus droebachiensis }^{\mathrm{i}} \\
\text { Strongylocentrotus intermedius }^{\mathrm{d}} \\
\text { Arbacia punctulata }^{\mathrm{j}} \\
\text { Paracentrotus lividus }^{\mathrm{h}} \\
\text { Diadema setosum }^{\mathrm{g}}\end{array}$ & $\begin{array}{l}\text { Antarctic } \\
\text { Antarctic } \\
\text { Temperate } \\
\text { Temperate } \\
\text { Temperate } \\
\text { Temperate } \\
\text { Temperate } \\
\text { Tropical }\end{array}$ & $\begin{array}{l}6-8 \text { d hatched blastula } \\
20-23 \text { d pluteus } \\
2-3 \text { d pluteus } \\
2-3 \text { d pluteus } \\
\text { pluteus } \\
2-4 \text { d pluteus } \\
2 \text { d pluteus } \\
2 \text { d pluteus }\end{array}$ & $\begin{array}{r}6.9 \\
<0.2 \\
0.5 \\
1.8 \\
0.5-2.5 \\
13.9 \\
>1.1 \\
0.2-0.5\end{array}$ \\
\hline $\begin{array}{l}\text { Zinc } \\
\left(\mu \mathrm{g}^{-1}\right)\end{array}$ & $\begin{array}{l}\text { Sterechinus neumayeri }^{\mathrm{a}} \\
\text { Sterechinus neumayeri }^{\mathrm{a}} \\
\text { Centrostephanus rodgersii }^{\mathrm{m}} \\
\text { Heliocidaris tuberculata }^{\mathrm{n}} \\
\text { Heliocidaris erythrogramma }^{\mathrm{m}} \\
\text { Strongylocentrotus purpuratus }^{\mathrm{i}} \\
\text { Strongylocentrotus droebachiensis }^{\mathrm{i}} \\
\text { Arbacia punctulata }^{\mathrm{j}} \\
\text { Arbacia lixula }^{\mathrm{c}} \\
\text { Paracentrotus lividus }^{\mathrm{j}} \\
\text { Anthocidaris crassispina }^{\mathrm{e}} \\
\text { Hemicentrotus pulcherrimus }^{\mathrm{f}} \\
\text { Diadema setosum }^{\mathrm{g}}\end{array}$ & $\begin{array}{l}\text { Antarctic } \\
\text { Antarctic } \\
\text { Temperate } \\
\text { Temperate } \\
\text { Temperate } \\
\text { Temperate } \\
\text { Temperate } \\
\text { Temperate } \\
\text { Temperate } \\
\text { Temperate } \\
\text { Temperate } \\
\text { Temperate } \\
\text { Tropical }\end{array}$ & $\begin{array}{l}\text { 6-8 d hatched blastula } \\
20-23 \text { d pluteus } \\
3 \text { d pluteus } \\
3 \text { d pluteus } \\
7 \text { d juvenile } \\
2-3 \text { d pluteus } \\
2-3 \text { d pluteus } \\
2-4 \text { d pluteus } \\
3 \text { d pluteus } \\
2 \text { d pluteus } \\
1 \text { d pluteus } \\
2 \text { d pluteus } \\
2 \text { d pluteus }\end{array}$ & $\begin{array}{r}2230 \\
326.7 \\
289.4 \\
280 \\
26.8 \\
23 \\
27-51 \\
205 \\
10-100 \\
<33 \\
50-100 \\
10-20 \\
10-20\end{array}$ \\
\hline $\begin{array}{l}\text { Lead } \\
\left(\mathrm{mg} \mathrm{l}^{-1}\right)\end{array}$ & $\begin{array}{l}\text { Sterechinus neumayeri }^{\mathrm{a}} \\
\text { Strongylocentrotus purpuratus }^{\mathrm{i}} \\
\text { Strongylocentrotus droebachiensis }{ }^{\mathrm{i}} \\
\text { Arbacia punctulata }^{\mathrm{j}} \\
\text { Paracentrotus lividus }^{\mathrm{k}}\end{array}$ & $\begin{array}{l}\text { Antarctic } \\
\text { Temperate } \\
\text { Temperate } \\
\text { Temperate } \\
\text { Temperate }\end{array}$ & $\begin{array}{l}6-8 \text { d hatched blastula } \\
2-3 \text { d pluteus } \\
2-3 \text { d pluteus } \\
2-4 \text { d pluteus } \\
3 \text { d pluteus }\end{array}$ & $\begin{aligned}>3.2 \\
<9.7 \\
<9.7 \\
<32.5 \\
0.21-0.62\end{aligned}$ \\
\hline
\end{tabular}

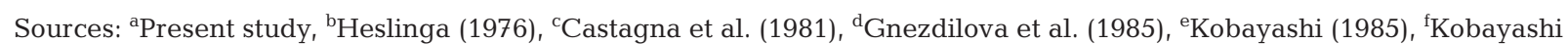
(1990), ' Kobayashi (1994), hPagano et al. (1986), 'Dinnel (1990), 'B Bay et al. (1993), ${ }^{\mathrm{k}}$ Warnau \& Pagano (1994), ${ }^{1}$ Ramachandran et al. (1997), ${ }^{\mathrm{m}} \mathrm{King}$ (1999), ${ }^{\mathrm{n}}$ C.K.K. (unpubl.), ${ }^{\circ}$ A.W.T. EnSight (unpubl.)

tests, the amphipod was more sensitive to cadmium than were sea-urchin larvae (amphipod 4 d LC50 = $1169 \mu \mathrm{g} \mathrm{l} \mathrm{l}^{-1}, 8 \mathrm{~d}$ LC50 = $533 \mu \mathrm{g} \mathrm{l^{-1 }}, 5 \mathrm{~h}$ behavioural NOEC > $1000 \mu \mathrm{g} \mathrm{l}^{-1}$; Greve 1997, Duquesne et al. 2000). However, amphipods were much less sensitive to copper than sea urchin larvae (amphipod $4 \mathrm{~d}$ LC50 = $988 \mu \mathrm{g} \mathrm{l}^{-1}, 8 \mathrm{~d} \mathrm{LC} 50=502 \mu \mathrm{g} \mathrm{l}^{-1}, 5 \mathrm{~h}$ behavioural NOEC $>100 \mathrm{\mu g} \mathrm{l}^{-1}$; Greve 1997, Duquesne et al. 2000).
A comparative discussion of the response to toxins by Arctic and Antarctic biota is almost impossible because the paucity of published information does not permit comparison among analogous species or contaminant types. However, Arctic invertebrates, including amphipods and mysids, have been found to be surprisingly tolerant of zinc and lead (Chapman 1993, Chapman \& McPherson 1993). Embryonic development of 
Sterechinus neumayeri was also relatively insensitive to lead, with an EC50 $>3.2 \mathrm{mg} \mathrm{l}^{-1}$, which is comparable to the LC50s measured for 2 Arctic amphipod species (>3.5 $\mathrm{mg} \mathrm{l}^{-1}$; Chapman 1993). Development of S. neumayeri to the hatched blastula stage (6 to $8 \mathrm{~d}$ ) was slightly more sensitive to zinc (EC50 $=2.23 \mathrm{mg} \mathrm{l}^{-1}$ ) than the $4 \mathrm{~d}$ LC50 tests using Arctic amphipods (LC50 for 3 species $>11.8 \mathrm{mg} \mathrm{l}^{-1}$ ) and mysids (LC50 $>50 \mathrm{mg} \mathrm{l}^{-1}$; Chapman \& McPherson 1993).

\section{Use of toxicity tests in Antarctic marine environments}

Toxicity tests have 2 main applications. They have been widely used in temperate regions to indicate the concentrations of single contaminants that may cause ecologically significant effects, and these data have been used to establish acceptable environmental standards. Toxicity tests have also been used to determine the environmental risk associated with complex mixtures, such as sewage effluent, the individual components of which may not be known. The toxicity tests based on the early life history of Sterechinus neumayeri reported here have the potential to be used for both these purposes. Despite the greater sensitivity of the long-term test, the 6 to $8 \mathrm{~d}$ development test provides reliable and repeatable results in a much shorter time (approximately $1 / 3$ that of the 2 -arm pluteus test). However, if a particularly sensitive test is required for potentially less toxic samples, then continued exposure through to the 2-arm pluteus stage would be useful and better able to detect effects resulting from lower levels of contaminants.

As the Antarctic environment is in many ways different from temperate regions, and marine organisms living in Antarctic waters have adapted physiologically to their unique environment, it is unreasonable to assume that emission standards developed using the response of temperate species to contaminants will be directly applicable to the Antarctic. That factors such as the time for development of larvae are so different for Antarctic species is a very strong argument in support of the use of local species under ambient conditions to determine the ecological significance of toxicity. If toxicity tests are to provide ecologically meaningful results they must be based on end-points which are relevant to the survival of the test organism. They must also be realistic in terms of the likely exposure of the organism to the contaminant in the real world. Anthropogenic inputs of contaminants in Antarctic marine environments may be short-term pulse events (e.g. fuel and oil spills), or may be more continuous (e.g. the flux of contaminants from disused waste disposal sites in summer, and the discharge of sewage effluent). The test reported here is based on a development process that takes much longer than for similar temperate species and for this reason could be criticised as being overly sensitive. However, because the larvae of the Antarctic species take longer to develop, the species may be more vulnerable to the effects of contaminants.

A test such as this, based on long-term exposure, would not be relevant if extended exposure was unlikely to occur in the natural setting. One particular characteristic of the Antarctic environment, the cover of sea-ice, does increase the likelihood of extended exposure of benthic and planktonic organisms to contaminants. For much of the year, the sea-surface near the coast of Antarctica is covered with ice that is frequently $\geq 1 \mathrm{~m}$ in thickness. This ice prevents the formation of wind-driven currents and significantly reduces mixing (Tate et al. 2000). Water held within enclosed bays, such as Brown Bay near Casey, may therefore be almost stationary for very long periods until the sea-ice is blown out by a strong wind event in summer. This effect, by reducing mixing in the water column, also may reduce the dispersion of contaminants and the dispersal of planktonic organisms including vulnerable early life history stages of many benthic invertebrates. This has the potential to increase the chance that planktonic organisms are retained within a particular body of water and are subjected to extended exposure to contaminants.

This study does not provide a definitive answer to whether Antarctic species are more or less sensitive to contaminants than species from warmer regions. This question will only be resolved with the accumulated results of toxicity tests applied to a range of Antarctic species using a variety of contaminants. This is the first reported study to indicate that an Antarctic species might be more sensitive to some contaminants than similar species from warmer regions. Increased sensitivity appears to be the direct result of the longer development time and hence increased time for exposure as the Antarctic species develop to a particular stage.

Acknowledgements. We are grateful to members of the 50th and 51th ANARE expeditions to Casey for their assistance with all aspects of the Antarctic fieldwork. Special thanks to J. Stark for his help in preparing and organising equipment for the trips to Antarctica. Thanks to J. Stark, A. Tabor and P. Goldsworthy for the collection of animals, to T. McCarron and G. Wiseman for the maintenance of aquarium facilities and equipment, and to S. Pearce for help in the laboratory and with seawater collections. Thanks also to I. Snape for chemical analyses and to C. Hickey for allowing us access to unpublished data. P. Selvakumaraswamy, M. Byrne and 3 anonymous reviewers provided useful criticism and improved the manuscript. This research was supported by the Australian Antarctic Division and the Australian Antarctic Advisory Committee (Project no. 2201). 


\section{LITERATURE CITED}

Abollino O, Aceto M, Sacchero G, Sarzanini G, Mentasti E (1996) Distribution of minor and trace metals in lake and sea environments (Antarctica). Ann Chimica 86:299-243

Arntz WE, Brey T, Gallardo VA (1994) Antarctic zoobenthos. Oceanogr Mar Biol Annu Rev 32:241-304

Bargagli R, Nelli L, Ancora S, Focardi S (1996) Elevated cadmium accumulation in marine organisms from Terra Nova Bay (Antarctica). Polar Biol 16:513-520

Bargagli R, Monaci F, Sanchez-Hernandez JC, Cateni D (1998) Biomagnification in an Antarctic marine coastal food web. Mar Ecol Prog Ser 169:65-76

Bay S, Greenstein D (1994) Purple sea urchin embryo development test method. Southern California Coastal Water Research Project, Westminster, CA, p 1-22

Bay S, Burgess R, Nacci D (1993) Status and applications of echinoid (Phylum Echinodermata) toxicity test methods. In: Landis W, Hughes JS, Lewis MA (eds) Environmental toxicity and risk assessment, ASTM STP 1179. American Society for Testing and Materials, Philadelphia, PA, p 281-321

Bayne BL, Gabbott PA, Widdows J (1975) Some effects of stress in the adult on the eggs and larvae of Mytilus edulis L. J Mar Biol Assoc UK 55:675-689

Bayne BL, Holland DL, Moore MN, Lowe DM, Widdows J (1978) Further studies on the effects of stress in the adult on the eggs of Mytilus edulis. J Mar Biol Assoc UK 58: 825-841

Berkman PA, Nigro M (1992) Trace metal concentration in scallops around Antarctic: extending the mussel watch programme to the Southern Ocean. Mar Pollut Bull 24(6): 322-323

Bosch I, Beauchamp KA, Steele ME, Pearse JS (1987) Development, metamorphosis, and seasonal abundance of embryos and larvae of the Antarctic sea urchin Sterechinus neumayeri. Biol Bull 173:126-135

Brey T, Gutt J (1991) The genus Sterechinus (Echinodermata: Echinoidea) on the Weddell Sea shelf and slope (Antarctica): distribution, abundance and biomass. Polar Biol 11: 227-232

Castagna A, Sinatra F, Scalia M, Capodicasa V (1981) Observations of the effect of zinc on the gametes and various developmental phases of Arbacia lixula. Mar Biol 64: 285-289

Chapman PM (1993) Are Arctic marine invertebrates relatively insensitive to metals? Environ Toxicol Chem 12: 611-613

Chapman PM, McPherson C (1993) Comparative zinc and lead toxicity tests with Arctic marine invertebrates and implications for toxicant discharges. Polar Rec 168: $45-54$

Cleveland L, Little EE, Petty JD, Johnson BT, Lebo JA, Orazio CE, Dionne J, Crockett A (1997) Toxicological and chemical screening of Antarctic sediments: use of whole sediment toxicity tests, microtox, mutatox and semipermeable membrane devices (SPMDs). Mar Pollut Bull 34(3): 194-202

Cole CM, Snape I, Gore DB, Reville AT, Riddle MJ (2000) Contaminants in the Antarctic environment III: Chemical and physical processes that influence contaminants in cold regions. In: Hughson T, Ruckstuhl C (eds) ISCORD 2000 Proceedings of the 6th International Symposium on Cold Region Development, 31 January-4 February, 2000, Hobart, TAS. Office of Antarctic Affairs, Hobart, TAS, p $128-131$

Cripps GC (1992a) Natural and anthropogenic hydrocarbons in the Antarctic marine environment. Mar Pollut Bull 25: 266-273

Cripps GC (1992b) The extent of hydrocarbon contamination in the marine environment from a research station in the Antarctic. Mar Pollut Bull 25:288-292

de Moreno JEA, Gerpe MS, Moreno VJ, Vodopivez C (1997) Heavy metals in Antarctic organisms. Polar Biol 17: $131-140$

Deprez P, Arens M, Locher H (1999) Identification and assessment of contaminated sites at Casey Station, Wilkes Land, Antarctica. Polar Rec 35(195):299-316

Dinnel PA (1990) Summary of toxicity testing with sea urchin and sand dollar embryos. In: Chapman GA (ed) Culture and toxicity testing of West Coast marine organisms. Proceedings of a workshop, February 27-28, 1990, Sacramento, CA. US EPA, Newport, OR, p 55-62

Dinnel PA, Link JM, Stober QJ, Letourbneau MW, Roberts WE (1989) Comparative sensitivity of sea urchin sperm bioassays to metals and pesticides. Arch Environ Contam Toxicol 18:748-755

Duquesne S, Riddle M, Schulz R, Liess M (2000) Potential of the gammarid Paramoera walkeri as a biological indicator for Antarctic ecosystems based on toxicity and bioaccumulation of various contaminants. Aquat Toxicol 49:131-143

Emlet RB, McEdward LR, Strathmann RR (1987) Echinoderm larval ecology viewed from the egg. In: Jangoux M, Lawrence JM (eds) Echinoderm studies, Vol 2. AA Balkema, Rotterdam, p 55-136

Esposito A, Cipollaro M, Corsale G, Ragucci E, Giordano GG, Pagano GG (1986) The sea urchin bioassay in testing pollutants. In: Giam GS, Dou HJM (eds) Strategies and advanced techniques for marine pollution studies: Mediterranean Sea. Springer-Verlag, Berlin, p 447-455

Ernst W, Klages M (1991) Bioconcentration and biotransformation of ${ }^{14} \mathrm{C}$-hexachlorocyclohexane and ${ }^{14} \mathrm{C}$-hexachlorobenze in the Antarctic amphipod Orchomene plebs (Hurley, 1965). Polar Biol 11:249-252

George SB, Cellario C, Fernaux L (1990) Population differences in egg quality of Arbacia lixula (Echinodermata: Echinoidea): proximate composition of eggs and larval development. J Exp Mar Biol Ecol 141:107-118

Gnezdilova SM, Khristoforova NK, Lipina IG (1985) Gonadotoxic and embryotoxic effects of cadmium in sea urchins. In: Salanki J (ed) Heavy metals in water organisms. Akademiai Kiado, Budapest, p 239-251

Green G, Nichols PD (1995) Hydrocarbons and sterols in marine sediments and soils at Davis Station, Antarctica: a survey for human-derived contamination. Antarct Sci 7(2): 137-144

Greve M (1997) Toxicity of heavy metals and an organic contaminant to the Antarctic gammarid Paramoera walkeri (Stebbing). MSc thesis, University of Groningen

Helm MM, Holland DL, Stephenson RR (1973) The effect of supplementary algal feeding of a hatchery breeding stock of Ostrea edulis on larval vigour. J Mar Biol Assoc UK 53:673-684

Heslinga GA (1976) Effects of copper on the Coral Reef echinoid Echinometra mathaei. Mar Biol 35:155-160

Honda K, Yamamoto Y, Tatsukawa R (1987) Distribution of heavy metals in Antarctic marine ecosystem. Proc NIPR Symp Polar Biol 1:184-197

King CK (1999) The impact of metals and organic contaminants on the development of marine invertebrates from the $\mathrm{Cl}$. Echinoidea and $\mathrm{Cl}$. Bivalvia. $\mathrm{PhD}$ thesis, University of Sydney

Klockner K, Rosenthal H, Willfuhr J (1985) Invertebrate bioassays with North Sea water samples I. Structural effects on 
embryos and larvae of serpulids, oysters, and sea urchins. Helgol Meeresunters 39(1):1-19

Kobayashi N (1980) Comparative sensitivity of various developmental stages of sea urchins to some chemicals. Mar Biol 58:163-171

Kobayashi N (1985) Marine pollution bioassay by sea urchin eggs, an attempt to enhance accuracy II. Publ Seto Mar Biol Lab 30(4/6):213-226

Kobayashi N (1990) Marine pollution bioassay by sea urchin eggs, an attempt to enhance sensitivity. Publ Seto Mar Biol Lab 34(4/6):225-237

Kobayashi N (1991) Marine pollution bioassay by using sea urchin eggs in the Tanabe Bay, Wakayama Prefecture, Japan, 1970-1987. Mar Pollut Bull 23:709-713

Kobayashi N (1994) Application of eggs of the sea urchin Diadema setosum in marine pollution bioassays. Phuket Mar Biol Cent Res Bull 59:91-94

Lenihan HS (1992) Benthic marine pollution around McMurdo station, Antarctica: a summary of findings. Mar Pollut Bull 25(9-12):318-323

Lenihan HS, Oliver JS (1995) Anthropogenic and natural disturbances to marine benthic communities in Antarctica. Ecol Appl 5(2):311-326

Lenihan HS, Oliver JS, Oakden JM, Stephenson MD (1990) Intense and localized benthic marine pollution around McMurdo Station, Antarctica. Mar Pollut Bull 21(9): 422-430

Lenihan HS, Kiest KA, Conlan KE, Slattery PN, Konar BH, Oliver JS (1995) Patterns of survival and behavior in Antarctic benthic invertebrates exposed to contaminated sediments: field and laboratory bioassay experiments. J Exp Mar Biol Ecol 192:233-255

Ling N, Hickey CW, Burton GA (1998) Are Antarctic marine organisms sensitive to anthropogenic pollutants? NZ Nat Sci 23:106

Locarnini SJP, Presley BJ (1995) Trace element concentrations in Antarctic krill, Euphausia superba. Polar Biol 15(4): $283-288$

Pagano G, Cipollaro M, Corsale G, Esposito A, Ragucci E, Giordano GG, Trieff NM (1986) The sea urchin: bioassay for the assessment of damage from environmental contaminants. In: Cairns J Jr (ed) Community toxicity testing, ASTM STP 920. American Society for Testing and Materials, Philadelphia, PA, p 66-92

Pearse JS, Giese AC (1966) Food, reproduction and organic constitution of the common Antarctic echinoid Sterechinus neumayeri (Meissner). Biol Bull 130(3):387-401

Editorial responsibility: Otto Kinne (Editor), Oldendorf/Luhe, Germany
Percy JA (1977) Responses of Arctic marine benthic crustaceans to sediments contaminated with crude oil. Environ Pollut 13:1-10

Percy JA, Mullin TC (1977) Effects of crude oil on the locomotory activity of Arctic marine invertebrates. Mar Pollut Bull 8(2):35-40

Petri G, Zauke GP (1993) Trace metals in crustaceans in the Antarctic Ocean. Ambio 22(8):529-536

Ramachandran S, Patel TR, Colbo MH (1997) Effect of copper and cadmium on three Malaysian tropical estuarine invertebrate larvae. Ecotoxicol Environ Saf 36:183-188

Riebel PN, Percy JA (1990) Acute toxicity of petroleum hydrocarbons to the Arctic shallow-water mysid, Mysis oculata (Fabricius). Sarsia 75:233-232

Ringwood AH (1992) Comparative sensitivity of gametes and early developmental stages of a sea urchin species (Echinometra mathaei) and a bivalve species (Isognomon californicum) during metal exposures. Arch Environ Contam Toxicol 22:288-295

Risebrough RW, de Lappe BW, Younghans-Haug C (1990) PCB and PCT contamination in Winter Quarters Bay, Antarctica. Mar Pollut Bull 21:523-529

Scouller RC, Stark JS, Snape, I, Riddle MJ, Gore DB (2000) Contaminants in the Antarctic environment V. Accumulation in marine sediments. In: Hughson T, Ruckstuhl C (eds) ISCORD 2000 Proceedings of the 6th International Symposium on Cold Region Development, 31 January-4 February, 2000, Hobart, TAS. Office of Antarctic Affairs, Hobart, p 136-139

Stanwell-Smith D, Peck LS (1998) Temperature and embryonic development in relation to spawning and field occurrence of larvae of three Antarctic echinoderms. Biol Bull 194(1):44-52

Tate PM, Cathers B, Morris CM (2000) Contaminants in the Antarctic environment IV. Dispersion in the marine environment. In: Hughson T, Ruckstuhl C (eds) ISCORD 2000 Proceedings of the 6th International Symposium on Cold Region Development, 31 January-4 February, 2000, Hobart, TAS. Office of Antarctic Affairs, Hobart, p 132-135

Viarengo A, Canesi L, Mazzucotelli A, Ponzano E (1993) Cu, $\mathrm{Zn}$ and $\mathrm{Cd}$ content in different tissues of the Antarctic scallop Adamussium colbecki: role of metallothionein in heavy metal homeostasis and detoxification. Mar Ecol Prog Ser 95(1-2):163-168

Warnau M, Pagano G (1994) Developmental toxicity of $\mathrm{PbCl}_{2}$ in the echinoid Paracentrotus lividus (Echinodermata). Bull Environ Contam Toxicol 53(3):434-441

Submitted: October 4, 1999; Accepted: December 12, 2000 Proofs received from author(s): March 29, 2001 